\title{
Influence of Organizational Culture and Work Motivation on Employee Engagement of Corporate PT Pertamedika IHC
}

\author{
Maulana Nadiful Afkar ${ }^{1}$, Andita Sayekti ${ }^{1}$ \\ ${ }^{1}$ Department of Management, Faculty of Economics and \\ Management, IPB University \\ nadifulafkar@gmail.com
}

\begin{abstract}
Nowadays companies are facing with employee engagement problems. One way that can be done is to implement strong organizational culture in the company to increase employee engagement. Pertamedika IHC made a change in corporate culture that was expected to spur work motivation towards employee engagement in the company. Corporate Pertamedika IHC as the holding company has a big role in the application of corporate culture, because it is an example for business units. This study aimed to determine employee perceptions and analyze the influence of organizational culture, work motivation on employee engagement. The data used in this study were primary data and secondary data. The population in this study amounted to 79 employees with a sample of 68 respondents. The method of analysis in this research were descriptive analysis and multiple linear regression analysis. This study indicated a significant cultural relationship and work motivation simultaneously to employee engagement. Partially, organizational culture had no influence on employee engagement while work motivation affects employee engagement.
\end{abstract}

Keywords: Employee engagement, organizational culture, work motivation.

JEL : : M14

DOI $\quad:$ 10.24002/kinerja.v21i2.2481

Received : 10/28/2019 Reviewed: 01/02/2020 Final Version: 10/07/2020 


\section{INTRODUCTION}

Pertamedika IHC has a vision, mission, and corporate culture to realize the goals of the company in the short, medium, and long term. In 2017, the government of the Republic of Indonesia had a program to consolidate all state-owned hospitals. PT Pertamedika IHC has changed its vision, mission, and corporate culture to realize the Healthcare Indonesia corporation. These changes will shape the company's targets and achievements in the future. This is indicated by the increase in workload due to the increasing number of hospitals consolidated in one company. These changes also have a short-term and long-term influence on the work motivation of Pertamedika IHC employees, due to changes in individual and company performance targets that must be achieved even better. According to Robbins in Winardi (2011), "work motivation as a willingness to carry out high-level efforts to achieve organizational goals that are conditioned by the ability of efforts to meet certain individual needs".

Previously Pertamedika IHC had a corporate cultural value called "LA PRIMA" (Professional, Friendly, Qualified, Enthusiastic Service), then changed to "TRUST" (Trust, Reliability, Uniqueness, Speed Up, and Tactical) in 2017. This cultural change making employees have to know each of the company's cultural values so they can renew and implement the company's cultural values in their daily performance. Therefore, organizations create a culture that is defined by meaningful work, good employee engagement, healthy work and organization, and strong leadership that is able to surpass the performance of colleagues and will usually defeat competitors in attracting top talent (Deloitte University 2015).

According to Robbins and Judge in Puspadewi (2015), employee engagement is an employee's individual involvement, satisfaction, and individual enthusiasm with the work they do. It is undeniable that employee job satisfaction is one of the factors that influence employee engagement every employee. Pertamedika IHC conducts a worker satisfaction survey every year.

Table 1 Percentage of IHC Pertamedika employee satisfaction surveys in 2018

\begin{tabular}{lc}
\hline \multicolumn{1}{c}{ Indicator } & Percentage of satisfaction (\%) \\
\hline Remuneration & 62 \\
Career Development & 61 \\
Work Atmosphere & 80 \\
Work Culture & 81 \\
Education and training & 62 \\
Vision, mission, and Corporate Culture & 57 \\
\hline
\end{tabular}

Table 1 shows some assesments indicators of employee satisfaction. Work culture is an indicator that has the highest level of satisfaction. Conversely, the lowest satisfaction indicators are found in the indicators of vision, mission, and corporate culture. This is due to the lack of socialization from the company regarding the implementation of the vision, mission, and corporate culture for employees, so that employees have not been able to implement and internalize corporate cultural values in their daily activities and work programs. 
Pertamedika IHC Corporate has a big role in the application of new corporate culture. As the holding company of the hospital holding company, Pertamedika IHC corporate is a reference and example for all business units or hospitals that it supports in the implementation of corporate culture. Therefore, the need for understanding, application and internalization of the corporate culture for Pertamedika IHC corporate employees, which is an example for other business units in daily work, is expected to increase employee motivation to create strong employee engagement for the company. There is no related research conducted at the Pertamedika IHC corporation makes researchers interested in examining the influence of organizational culture and work motivation on employee engagement on Pertamedika IHC corporate employees.

Based on the background, the research objectives are: (1) Knowing the perception of organizational culture in the IHC Corporate employees. (2) Knowing the perception of work motivation in corporate employees Pertamedika IHC. (3) Knowing employee engagement perceptions of Pertamedika IHC corporate employees. (4) Analyzing the influence of organizational culture and work motivation on employee engagement on Pertamedika IHC corporate employees.

The benefits of this research are: (1) For researchers, can increase knowledge and insight about the understanding of human resource management science, especially in the concept of organizational culture, work motivation, and employee engagement. (2) For companies, can be input and evaluation for the leadership of the company in measuring the extent to which corporate employees can implement company culture, employee motivation and how much employee engagement in corporate employees Pertamedika IHC. (3) For academics, it can be used as a reference or reference material for further research.

\section{LITERATURE REVIEW}

\subsection{Organizational Culture}

\subsubsection{Organizational Culture in PT Pertamedika IHC}

The company's cultural values based on Pertamedika IHC's managing director regulations are as follows:

1. Trust, which is building trust from all employees and management, patients, business partners and stakeholders with the implementation of quality processes and supporting good corporate governance (GCG).

2. Reliability, which shows the reliability of standardized institutions in providing services to customers.

3. Uniqueness, which is creating health care products that are different and superior so that they can become a trend setter and trend leader.

4. Speed up, which is always to accelerate service and operations to provide continuous service quality improvement.

5. Tactical, which is utilizing all resources tactically, effectively and efficiently in achieving goals. 


\subsection{Work Motivation}

According to Abraham Maslow in Winardi (2011), there are five levels of individual needs that are arranged in a hierarchy:

1. Physiological needs

At the lowest level of the hierarchy at the starting point of motivation theory, there are human physiological needs. These needs that need to be met to maintain survival.

2. Security needs

These needs cover all the needs for a safe and protected environment, both physically and emotionally, and free from threats including an orderly environment and freedom from violence.

3. Belonging needs

At this level of need an individual wants to belong to certain groups, he wants to associate with other parties, he wants to be accepted by his colleagues, and he wants to share and accept the attitude of friendship and affection.

4. Esteem needs

At this level of need, individuals have the need for self-appreciation and appreciation from other parties. The need for self-esteem includes selfconfidence, achievement, competence, knowledge, self-esteem, and freedom and independence (non-dependence)

\section{Self-actualization needs}

This need is a need to fulfill oneself by maximizing the expertise and potential that exists in each individual.

\subsection{Employee Engagement}

According to Wiley (2010), measurement of employee engagement can be done by using a combination of 4 elements in each individual employee:

1. Pride, definitely the creation of pride in employees for being involved in the progress of the company.

2. Satisfaction, definitely the creation of employee satisfaction with their work.

3. Advocacy, that is employees feel they are supported by all aspects (superiors, coworkers, subordinates, families).

4. Commitment, definitely creating a desire in employees to survive in the company.

\subsection{The Relationship Between Organizational Culture and Employee Engagement}

According to Homans in Brenyah and Obuobisa (2017), when employees have a perception that organizational culture allows them to have a good relationship with other employees in the organization, where they need support and power among others, they tend to give everything in a dedicated manner so that work with spirit. When the culture of an organization is not valued by its employees, employees have a higher tendency to quit than keep working in the company (Schein in Brenyah and Obuobisa, 2017). 


\section{RESEARCH METHOD}

\subsection{Population and Sample}

This study uses a purposive sampling method where researchers determine a criterion to determine the research sample. The criteria determined are employees who have manager positions, assistant managers, staff, and company secretaries. So that the study population amounted 79 employees. Data collection methods in this study used a questionnaire that was distributed directly and online to the population in the study. Then the determination of the sample is determined by the Slovin method, so that a sample of 68 respondents is obtained.

\subsection{Data Processing and Analysis Methods}

This study conducted a descriptive analysis to make the data collected from respondents more informative. Then to analyze the influence of organizational culture and work motivation on employee engagement using multiple linear regression analysis. Data processing is done using the help of applications, such as Microsoft Excel software and SPSS 25.0 software for windows.

\section{RESULT AND DISCUSSION}

\subsection{Respondent Characteristic}

Respondent characteristics in this study were analyzed based on the characteristics of age range, marital status, employee status, length of work in the company, and the last level of education taken by the respondent. The data can be seen in Table 2.

Table 2. Respondent characteristics

\begin{tabular}{llcc}
\hline Criteria & \multicolumn{1}{c}{$\begin{array}{c}\text { Respondent } \\
\text { Characteristic }\end{array}$} & $\begin{array}{c}\text { Amount } \\
\text { (People) }\end{array}$ & $\begin{array}{c}\text { Percentage } \\
(\%)\end{array}$ \\
\hline Age (years) & $21-30$ & 5 & 9 \\
& $31-40$ & 17 & 23 \\
& $\mathbf{4 1 - 5 0}$ & $\mathbf{3 6}$ & $\mathbf{5 3}$ \\
& $50-56$ & 10 & 15 \\
\hline Marital Status & Married & $\mathbf{6 2}$ & $\mathbf{9 1}$ \\
& Single & 6 & 9 \\
& Others & 0 & 0 \\
\hline Worker status & Permanent Worker & $\mathbf{6 1}$ & $\mathbf{9 0}$ \\
& Part Time Worker & 7 & 10 \\
\hline Length of Work & $<5$ & 10 & 15 \\
(age) & $5-10$ & 9 & 13 \\
& $11-15$ & 9 & 13 \\
& $16-20$ & 17 & 25 \\
& $\mathbf{2 0 - 3 0}$ & $\mathbf{2 3}$ & $\mathbf{3 4}$ \\
\hline Education & Senior High School & 2 & 3 \\
& Vocational & 3 & 4 \\
& Bachelor & $\mathbf{4 2}$ & $\mathbf{6 2}$ \\
& Post graduate & 21 & 31 \\
\hline
\end{tabular}


Table 2 shows the respondents in this study were 68 respondents. According to Gallup (2016), in general the majority of Pertamedika IHC's corporate employees are currently in the age range of $41-50$ years, where the age range is included in Generation X, while employees with an age range of 50-56 years belong to the baby boomer's generation. Meanwhile, only a small number of employees belong to Generation $Y$ with an age range of 21-30 years and some employees are currently aged up to 39 years. This is reinforced by the majority of employees who already have status as permanent employees and are married. According to Soetrisno and Sutanto (2017), married employees have a higher work engagement compared to unmarried and divorced employees. This is because married employees have a great responsibility because their work is not only related to their personal lives but affects their families. Therefore, married employees do not think anymore to move from the company because work in the company has become a very important part of his life.

Corporate Corporation IHC requires senior employees who are experienced in running the company, because the corporation plays a major role in determining various company policies strategically. Most of IHC's Pertamedika corporate employees have served for a long time with the majority of employees having worked for 20-30 years in the company. With a long period of work, the majority of employees have felt several rotations and mutations in the internal work of the company, so employees have felt a variety of diverse problems and are able to carry out work that is in corporate corporations. The company is engaged in the field of health services, where the corporate as the highest position in the company's structure is filled with employees who have high competence and expert capabilities in the health sector. This is indicated by the majority of employees having educational background at the undergraduate and postgraduate level, where graduates of education in the fields of nursing, doctors, and specialist doctors become the dominant educational background in corporate employees of Pertamedika IHC.

\subsection{Employee Perception of Organizational Culture}

The results of employee perceptions of organizational culture can be seen in Table 3.

Table 3 Employee Perception of Organizational Culture

\begin{tabular}{lcc}
\hline \multicolumn{1}{c}{ Indicator } & Mean & Category \\
\hline ““TRUST”" & 3.31 & Strongly Agree \\
Reliability & 3.41 & Strongly Agree \\
Uniqueness & 3.10 & Agree \\
Speed Up & 3.23 & Agree \\
Tactical & 3.19 & Agree \\
\hline
\end{tabular}


Based on Table 3, employee perceptions of various indicators of organizational culture are categorized as agree and strongly agree. This shows that the knowledge and understanding of the employees towards the "TRUST" culture at the IHC Medicines is good.

The perception of employees with the highest average score is found in the reliability indicator. This shows that employees who work at Pertamedika IHC corporations have expertise in their respective fields of work, so they can be relied upon whenever needed. Employees carry out work in accordance with the directions and procedures set by the company. With working time at Pertamedika $\mathrm{IHC}$ the majority of more than 20 years shows that employees are accustomed to dealing with various work problems that come anytime and anywhere so they can solve problems and find solutions to help leaders and companies.

The application of "TRUST" culture at Pertamedika IHC has links to each other in every cultural value. The value of "TRUST" shows the "TRUST" each employee has in the company management, business partners, and all stakeholders of Pertamedika IHC to foster the confidence of employees to carry out all business processes that are carried out at Pertamedika IHC, so that employees have good principles and ambitions and contribute in realizing a company into good corporate governance (GCG). On the other hand, the management has acted professionally in implementing various policies that are appropriate to the needs of employees and the company, so that the feedback makes this value of "TRUST" important in realizing the company's vision and mission.

Similarly, other corporate culture values, where the Uniqueness value shows corporate employees Pertamedika IHC with experience have a new or different way of completing work and make various innovations at work, Speed up values prove that employees can work quickly to improve the quality of company services and minimize the level of errors in work, as well as the value of Tactical shows that employees can complete work in a tactical and measurable manner so that these cultural values can create effectiveness and efficiency in the sustainability of daily business processes.

In the end, "TRUST"'s organizational culture applied by Pertamedika IHC encourages employees to work reliably, quickly and tactically for the company's progress in facing competitive competition with other similar companies. This is consistent with the opinion of Mohelska \& Sokolova in Mensah (2018) which states that an established organizational culture can create significant competitive advantages for an organization. Therefore, the importance of the introduction and socialization of "TRUST" culture by the company is not only for old employees, but also for new employees is also involved so that the implementation and internalization of company culture by every corporate employee of Pertamedika IHC can be carried out properly and well established. With a record of management or directors as corporate leaders must be a leader and an example for all employees of Pertamedika IHC in implementing corporate cultural values.

\subsection{Employee Perception of Work Motivation}

The results of Peramedika IHC's corporate employee perception of work motivation variables can be seen in Table 4. 
Table 4. Employee Perception of Work Motivation

\begin{tabular}{lcc}
\hline \multicolumn{1}{c}{ Indicator } & Mean & Category \\
\hline Physiological & 2.97 & Agree \\
Safety & 3.18 & Agree \\
Belonging & 3.26 & Strongly Agree \\
Esteem & 2.81 & Agree \\
Self-actualization & 3.10 & Agree \\
\hline
\end{tabular}

In Table 4 it can be seen that employee perceptions of the majority of work motivation indicators are categorized as agreed. However, there is the highest indicator with the category of perception strongly agree. The belonging indicator shows that corporate employees of Pertamedika IHC already have mutual respect for each other as good work partners. The emergence of comfort that each employee has can increase the sense of belonging as a family Pertamedika IHC. The majority of employees who are over 40 years old with more than 20 years of service show that the work undertaken at the IHC Pertamedika is now a very important and valuable part of themselves in life, because for employees almost or even part of their lives have served in the job and this company.

In other motivational indicators, physiological shows the basic and basic needs of corporate employees have been met. The corporation as the holding company has the highest workload and responsibility compared to Pertamina's business units or hospitals as the operational drivers of the company. Various tasks relating to policies for all Pertamedika IHC employees are carried out by Pertamedika IHC corporate employees. Therefore, corporate employees get more income from the company to meet their basic needs.

Pertamedika IHC as a company engaged in the service of health institutions provides priority health services for Pertamedika IHC employees. Likewise, with the existence of the HSE (Health, Safety, Environment) system in the company that provides guidelines for employees to work with good health, safety and safety at their respective workplaces. HSE programs that are tailored to the level of risk in each area of work make employees feel safe and comfortable at work. If at any time an emergency occurs, the employee already knows what must be done by the employee to protect and ensure himself safe.

Next the level of need to motivate employees is with esteem. In general, the need for appreciation for Pertamedika IHC's corporate employees is already good. However, some employees have the perception that there is still lack of appreciation, both verbal and written appreciation and recognition for outstanding employees both inside and outside the company. This is important because every employee generally wants to be recognized for his work or other achievements that are considered to exceed his work targets. The recognition can be given in the form of awards in the form of oral or written. Similarly, the award of certificates, placards, or other prizes to appreciate employees who excel.

The next motivational indicator is the need for self-actualization (satisfaction). In general, Pertamedika IHC corporate employees can develop their potential within the company. Various challenges faced from outside the company spur employees to fix and improve their performance. Corporate employees can take new things from these challenges and make it a motivation to develop themselves. 
Likewise, with the existence of a system of employee rotation and mutation carried out to improve the competence and quality of employee performance.

\subsection{Employee Perception on Employee Engagement}

The results of Peramedika IHC's corporate employee perceptions of employee engagement can be seen in Table 5.

Table 5. Employee Perception on employee engagement

\begin{tabular}{lcc}
\hline \multicolumn{1}{c}{ Indicator } & Mean & Category \\
\hline Pride & 3.04 & Agree \\
Satisfaction & 2.98 & Agree \\
Advocation & 2.99 & Agree \\
Commitment & 3.13 & Agree \\
\hline
\end{tabular}

Employees' perception of employee engagement in Table 5 shows that employees have the perception of agreeing to all statements of various indicators given. Commitment indicator has the highest average score. This shows that Pertamedika IHC's corporate employees have a good commitment in working. Employees have a high totality in completing work without being influenced by personal problems or other problems. The majority of employees who work for more than 20 years show that employees continue to make the best contribution that can be given to the company. Therefore, no longer working in a company makes it difficult for employees or do not think about changing jobs at other companies. The pride in employees of the work and place of work proves that the company has a good self-esteem so that arises pride that is shown by sharing experiences or stories about work and the company to others.

Furthermore, the satisfaction of Pertamedika IHC's corporate employees is at a good level. However, satisfaction with the salaries earned by corporate employees must be underlined by the company. Each employee's income or salary is difficult to measure because his satisfaction has different indicators of satisfaction and needs. Likewise, the existence of work facilities that are considered unsatisfactory by some corporate employees to support work. Therefore, companies need to provide additional work facilities that are considered to be able to increase the effectiveness and efficiency of employee work.

The need for a program from the company to increase employee engagement, such as holding corporate employee gatherings in an informal setting to foster and enhance closer relations for fellow employees and between leaders and staff. Likewise, involving employees in providing a forum for aspirations to propose certain policies that can be felt by corporate employees of Pertamedika IHC. 


\subsection{The Effect of Organizational Culture and Work Motivation on Employee Engagement}

\subsubsection{Multiple linear regression analysis}

\subsubsection{Coefficient of determination}

Table 6. the coefficient of determination results

\begin{tabular}{rrrrrr}
\multicolumn{1}{c}{ Model } & $\mathrm{R}$ & $\mathrm{R}$ Square & $\begin{array}{c}\text { Adjusted } \mathrm{R} \\
\text { Square }\end{array}$ & $\begin{array}{c}\text { Std. Error of } \\
\text { the Estimate }\end{array}$ & Durbin- Watson \\
\hline 1 & $.759^{\mathrm{a}}$ & .575 & .562 & 4.376 & 2.006 \\
\hline
\end{tabular}

Adjusted R-Square value obtained from the data processing is 0.562 or $56.2 \%$. This means that the percentage of the influence of organizational culture and work motivation simultaneously on employee engagement is $56.2 \%$. It can be said that $56.2 \%$ employee engagement is influenced by organizational culture and work motivation in research, while the remaining $43.8 \%$ is explained by other factors which not explained in this study.

\subsubsection{Simultaneous F Test}

$\mathrm{F}$ test results can be seen in Table 7.

Table 7. F Test results ANOVA $^{a}$

\begin{tabular}{lllllr}
\hline \multicolumn{1}{c}{ Model } & Sum of Squares & \multicolumn{1}{c}{ Df } & Mean Square & F & Sig. \\
\hline Regression & 1686.693 & 2 & 843.347 & 44.038 &, $000^{\mathrm{b}}$ \\
Residual & 1244.778 & 65 & 19.150 & & \\
Total & 2931.471 & 67 & & & \\
\hline
\end{tabular}

$F$ test results indicate that the Fcount value of 44,038 with a significance level of 0,000 . These results indicate that the Fcount value is greater than Ftable $(44,038>3.14)$ and significance $(0,000<0.050)$ so that $H 03$ is rejected and $H 13$ is accepted. Therefore, organizational culture and work motivation simultaneously influence (together) on employee engagement.

\subsubsection{Partial $t$ Test}

T test results on the regression processing output can be seen in Table 8 .

Table 8. T Test Result

\begin{tabular}{lccccc}
\hline \multicolumn{1}{c}{ Model } & \multicolumn{2}{c}{$\begin{array}{c}\text { Unstandardized } \\
\text { Coefficients }\end{array}$} & $\begin{array}{c}\text { Standardized } \\
\text { Coefficients }\end{array}$ & $\mathrm{T}$ & Sig. \\
& $\mathrm{B}$ & Std. Error & Beta & & \\
\hline (Constant) & 4.489 & 6.594 & & .681 & .498 \\
Budaya Organisasi & .076 & .078 & .097 & .970 & .336 \\
Motivasi kerja & .777 & .111 & .697 & 6.965 & .000 \\
\hline
\end{tabular}


T test results on organizational culture variables have a significance value of 0.336 and Tcount value of 0.970 . Tcount value is smaller than Ttable value $(0.970$ $<1.9971)$ and significance value $(0.336>0.05)$, so the $H_{01}$ statement is accepted and $H_{11}$ is rejected. Therefore, organizational culture does not affect the employee engagement of Pertamedika IHC corporate employees.

While the $T$ test results on work motivation variables have a significance value of 0,000 and Tcount of 6,965 . Where the $T$ value is greater than the value of $T$ table $(6,965>1.9971)$ and the significance value $(0,000<0.05)$ so that the statement $H_{02}$ is rejected and $H_{12}$ is accepted. This shows that work motivation has a significant influence on employee engagement in Pertamedika IHC corporate employees.

Based on the results of the thest in Table 8, the results of the analysis of the influence of organizational culture and work motivation on employee engagement if included in the multiple linear regression equation, the regression model is obtained as follows:

$$
\begin{gathered}
Y=a+b X_{1}+c X_{2} \\
Y=4.489+0.076 X_{1}+0.777 X_{2}
\end{gathered}
$$

The coefficient value of organizational culture $(\mathrm{X} 1)$ is 0.076 with a positive sign. It shows that if organizational culture increases one unit it will increase employee engagement by 0.076 . It can be concluded that organizational culture (X1) has no influence and is not significant to employee engagement (Y). This shows that "TRUST"'s corporate culture which was implemented in 2017 at Pertamedika IHC could not be realized properly. Even though employees already know and understand "TRUST"'s cultural values, it will be better if employees can implement and internalize these cultural values in a variety of work programs implemented within the scope of the company. According to Tinypulse (2019), only less than one third of employees in the company currently value the company culture well. This means the company must be better at increasing the socialization of the company's culture to employees with a deeper explanation so that employees implement and live up to the application of the company's cultural values. Corporate culture also plays an important role in developing and maintaining work motivation levels among employees. Currently an employee can work more effectively and bring out the best potential, when there is a match between the motivation of individual employees with the culture of the organization or company (Yusof et al 2016).

Furthermore, the coefficient of work motivation (X2) is 0.777 with a positive sign. This shows that if work motivation increases by one unit, it will increase employee engagement by 0.777 . Therefore, it can be concluded that work motivation (X2) has a positive and significant influence on employee engagement. Work motivation is important and fundamental for Pertamedika IHC corporate employees. Almost all Pertamedika corporate employees have families. Where married employees have a high work, engagement compared to unmarried and divorced employees (Soetrisno and Sutanto 2017). This is due to the first encouragement and support from the family so that employees can be motivated at work. In addition, employees need awards as a form of self-appreciation because they have succeeded in carrying out the work very well or get satisfactory work performance. 
While the employee engagement variable $(Y)$ has a constant value of 4,489 assuming the other variables are of fixed value or 0 . This shows that without being influenced by organizational culture and work motivation, Pertamedika IHC's corporate employees already have good employee engagement. The majority of corporate employees aged over 40 years and working with more than 20 years shows that employees have worked by giving all the best capabilities with totality and high commitment to the company, so employees can do every job thoroughly and and do not think about moving the work of the IHC Pertamedika. The career path of employees who have entered the peak period and the retirement period that is no longer in the company is the reason employees do not want to leave Pertamedika IHC. This is in line with the opinion according to Mcleod in llyasa (2015) explaining that there is an attachment not only physically but emotionally attached to employees with work and company, then motivated and able to provide the best ability to be successful from a series of benefits felt for each employees and company.

\subsection{Recommendation for Company}

The researcher provides recommendations for companies that are explained based on management functions (planning, organizing, actuating, controlling) in the Table 9.

Table 9. Recommendation for company

\begin{tabular}{ll}
\hline Function of Management & \multicolumn{1}{c}{ Application } \\
\hline Planning & $\begin{array}{l}\text { Organize programs that can increase employee } \\
\text { engagement, such as corporate employee gatherings } \\
\text { at least once a year or twice. }\end{array}$ \\
& Disseminating corporate culture to all employees, \\
& both permanent and temporary employees. \\
& Develop certain criteria for employees who have \\
& performance exceeding targets and employees who \\
& perform poorly and to socialize reward and \\
& punishment from the company to employees.
\end{tabular}

Organizing Increasing collaboration and synergy between units / divisions in carrying out various work programs as well as providing input and solutions to problems encountered.

Coordinate and strengthen the corporate management of Pertamedika $\mathrm{IHC}$ in implementing organizational culture and increasing employee motivation.

Actuating Give awards in the form of certificates, placards, or additional bonus incentives for employees who have the best performance every month and for employees who excel outside the company.

Give punishment to employees who commit violations.

Involving employees in the aspirations of specific decision-making aimed at employees. 


\begin{tabular}{ll}
\hline Function of Management & \multicolumn{1}{c}{ Application } \\
\hline Controlling & Evaluate the attendance and delay of employees \\
& entering the office. \\
& Evaluate employee performance. \\
& Evaluate the application of organizational culture to \\
& suit the needs of the company.
\end{tabular}

\section{CONCLUSION}

The results of research conducted on the influence of organizational culture and work motivation on employee engagement in Pertamedika IHC corporate can be concluded as follows:

1. Employees' perceptions of the organization's cultural values Pertamedika IHC consists of cultural values such as "TRUST", Reliability, Uniqueness, Speed Up, and Tactical can largely be categorized with the perception of agreeing with the various statements given. This shows that the organizational culture in corporate Pertamedika $\mathrm{IHC}$ is well known and understood by employees. The indicator with the highest value in the organizational culture is the cultural value of Reliability.

2. Employees' perception of work motivation consists of physiological, safety, belonging, esteem, and self-actualization indicators, the majority are perceived as agreeing with the statement given. This shows that the work motivation of the corporate Pertamedika IHC is quite good. The highest factor in work motivation indicators is in the belonging indicator.

3. Employee perception of employee engagement consists of indicators of pride, satisfaction, advocacy, and commitment categorized in agreement with the statement given. This shows that employee engagement in Pertamedika IHC's corporate employees is already classified as good. The highest factor in the employee engagement indicator is in the commitment factor.

4. Organizational culture and work motivation towards corporate employee engagement Pertamedika IHC has a significant simultaneous effect. Partially organizational culture has no influence and is not significant on employee engagement, while work motivation has a positive and significant influence on corporate employee engagement Pertamedika IHC.

\subsection{Suggestion}

For companies, in order to hold a corporate employee gathering Pertamedika IHC that is filled with a deeper agenda of corporate culture socialization, appreciation or appreciation for employees who excel to increase employee motivation, and the event is packaged in an informal or relaxed atmosphere so that closer and closer relations can be established between fellow employees and between leaders and staff so as to increase employee engagement.

For researchers, for further research can use different theories on related variables, especially in organizational culture. The theory or application of organizational culture in companies can be adjusted to explain trends or compatibility with organizational culture theory in general. 


\section{REFERENCES}

Aon Empowers Organizations and Individuals. 2018. 2018 Trends in Global Employee engagement [internet].[diunduh pada 2019 Juli 11]. Tersedia pada https://www.aon.com/2018-global-employee-engagement-trends/index.html.

Brenyah, S.R., Obuobisa-Darko, T. 2017. Organisational Culture and Employee Engagement within the Ghanaian Public Sector. Review Pub Administration Manag 5(3):1-7.

Deloitte University. 2015. Global Human Capital Trends 2015 Leading in the New World of Work [internet]. [diunduh pada 2019 Mei 21]. Tersedia pada https://www2.deloitte.com.

Edison, E., Anwar, Y., Komariyah, I. 2017. Manajemen Sumber Daya Manusia. Bandung (ID): Alfabeta.

Eva, T.S. 2018. Pengaruh Motivasi Kerja dan Budaya Organisasi Terhadap Employee engagement Karyawan Kantor Pusat PT Perkebunan Nusantara VIII Bandung [skripsi]. Bandung (ID): Universitas Pasundan.

Fadhila, N. 2018. Pengaruh Budaya Organisasi terhadap Employee engagement pada Pusat Penelitian Karet Bogor [skripsi]. Bogor (ID):Institut Pertanian Bogor.

Fatimah, H, Dharmawan, A.H., Sunarti, E., Affandi, M.J. 2015. Pengaruh Faktor Karakteristik Individu dan Budaya Organisasi terhadap Keterikatan Pegawai Generasi X dan Y. Jurnal Aplikasi Manajemen (JAM) 13(3):402-409.

Gallup. 2016. Millennials: The Job-Hopping Generation. Tersedia pada: https://www.gallup.com/workplace/231587/millennials-job-hoppinggeneration.aspx

Ghozali, I. 2013. Aplikasi Analisis Multivariate dengan Program IBM SPSS 21. Semarang (ID): Badan Penerbit Universitas Diponegoro.

Ilyasa. 2018. The Effect of Organization Culture, Knowledge Sharing and Employee Engagement on Employee Work Innovation. International Journal of Scientific Research and Management (IJSRM). 6(1):57-63.

Inanlou, Z, Ahn, J. 2017. The Effect of Organizational Culture on Employee Commitment: A Mediating Role of Human Resource Development In Korean Firms. The Journal of Applied Business Research. 33(1):87-94.

Joushan, S.A. 2015. Pengaruh Budaya Organisasi dan Employee engagement terhadap Kinerja Karyawan PT PLN (Persero) Area Bekasi [skripsi]. Bogor (ID): Institut Pertanian Bogor. 
Nazneen, A., Miralam MS, Qazi S. 2018. Influence of Employee engagement and Organizational Culture in High Performing Accredited University of Saudi Arabia. International Journal of Accounting and Financial Reporting. 18(4):180-194.

Njuguna, R.G. 2015. Influence of Organizational Culture on Employee Engagement at KCB Head Office [thesis]. Nairobi (KE): University of Nairobi.

Octaviani, S., Fakhri, M. 2016. Pengaruh Budaya Organisasi terhadap Employee engagement pada Fakultas Ekonomi dan Bisnis serta Fakultas Komunikasi dan Bisnis Universitas Telkom. Jurnal Valuta 2(2):156-170.

Pepra-Mensah, P., Kyeremeh, E.A. 2018. Organisational Culture: A Catalyst For Employee Engagement in The Ghanaian Public Sector? Global Journal of Human Resource Management 6(3):11-28.

Puspadewi, U.I. 2016. Analisis Tentang Employee Engagement pada Perusahaan Jasa (Studi Pada Karyawan Patra Jasa Covention Hotel Semarang). Diponegoro Journal of Management 5(3):1-14.

Rachmatullah, A, Susanty, A.I, Partono, A. 2015. Pengaruh Motivasi Kerja Terhadap Employee engagement (Studi Kasus di PT House the House Bandung). Jurnal e-proceeding of management 2(3):2919-2917.

Ricardianto, P. 2018. Human Capital Management. Jakarta (ID): STMT Trisakti Press.

Soetrisno, L.C.P., Sutanto, E.M. 2017. Pengaruh Keterikatan Kerja Dan Persepsi Dukungan Organisasional Terhadap Kinerja Karyawan Pt. Sukses Mekar Abadi. Jurnal AGORA 5(3):1-10.

Sugiyono. 2013. Metode Penelitian Pendidikan (Pendekatan Kuantitatif, Kualitatif, dan R\&D). Bandung (ID): Alfabeta.

Surbakti, R.T. 2014. Pengaruh Motivasi Kerja Terhadap Kinerja Karyawan Golongan 1 Universitas Katolik Parahyangan. E-Journal Graduate Unpar. 1(2):211-232.

Suripto, T. 2015. Meningkatkan Kinerja Karyawan Melalui Expectancy Theory Dalam Motivasi. Jurnal Ekonomi Syariah Indonesia. 5(2):115-123.

Tinypulse. 2019. The 2019 Employee engagement Report [internet]. [diunduh pada 2019 Juli 11]. Tersedia pada https://www.tinypulse.com/2019employee-engagement-report.

Wibowo. 2013. Budaya Organisasi Sebuah Kebutuhan untuk Meningkatkan Kinerja Jangka Panjang. Jakarta (ID): Rajawali Pers. 
Wiley, J.W. 2010. Strategic Employee Surveys: Evidence-Based Guidelines for Driving Organizational Success. San Francisco [US]: Jossey-Bass.

Winardi, J. 2011. Motivasi dan Pemotivasian dalam Manajemen. Jakarta (ID): Rajawali Pers.

Wulandari, N.A. 2016. Pengaruh Kepemimpinan, Budaya Organisasi, dan Kompensasi Terhadap Keterikatan Karyawan (Studi Kasus pada Bank Syariah Mandiri) [skripsi]. Jakarta (ID): UIN Syarif Hidayatullah Jakarta.

Yusof, H.S.M., Said, N.S.M., Ali, S.R.O. 2016. A Study of Organizational Culture and Employee Motivation in Private Sector Company. Journal of Applied Environmental and Biological Science. 6(3):50-56. 